\title{
CONTENT AND LANGUAGE INTEGRATED LEARNING AT AN EARLY AGE: POSSIBILITIES AND LIMITATIONS
}

\author{
Tilen Smajla \\ Elementary School Vojke Šmuc, Izola, Slovenia
}

\begin{abstract}
Content and Language Integrated Learning (CLIL) as an educational approach has a dual focus in which an additional language is used for the learning and teaching of both content and language (Coyle, Hood and Marsh, 2010, p. 1; Criado and Sánches, 2012). The research focuses on early foreign language learning (EFLL) through CLIL. A small scale research has been carried out in year three in an elementary school analysing parents' perceptions and attitudes regarding EFLL, the implementation of the CLIL approach, and wellbeing in class. The results were obtained by administering an anonymous questionnaire to parents of children in the aforementioned class and showed a high appreciation of the CLIL approach, further, the parents deem EFLL as a very important factor for the future work and study of their off-spring. In addition, the research showed the appreciation of parents for the wellbeing of their offspring in a foreign language class. The latter is of great importance, since it significantly lowers anxiety levels and boosts the learning impact.
\end{abstract}

Key words: CLIL, EFLL, young learners, parents'attitudes and perceptions, wellbeing.

\section{Introduction}

Internalisation and globalisation of learning environments, teaching methods as well as other factors have contributed to teachers' choice of teaching methods. Content and language integrated learning or shortly CLIL is a successful and one of the most endorsed communicative teaching methods that has been on the rise across Europe, since it has been successfully applied in class (Eurydice, 2006, p. 2; Ioannou-Georgiou, 2012, p. 495). CLIL has its root in the immersion programmes in Canada and partly in content-based instruction in the United States (Llinares, Morton and Whittaker, 2012, p. 1), with which it shares some similarities as well as differences, such as the language of instruction, teachers, starting age, teaching materials, language objectives, inclusion of immigrant students and research (Lasagabaster and Sierra, 2010, as cited in Llinares et. al, 2012, p. 2). The core feature of CLIL is that an additional language is used for the learning and teaching of language and content at the same time (Coyle, Hood and Marsh, 2010, p. 1; Criado and Sánches, 2012). The CLIL approach often uses a language that is not the student's native language which is perfectly in line with the European Commission's white paper (1995), where the objective of " $1+2$ policy" is set as a target. That additional language is often the learner's first foreign language, yet it may also be a second, home, some other community or heritage language (Coyle et al., 2010, p. 1). 


\section{Problem of the Research}

It is not unimportant who does the teaching according to method CLIL at an early stage. CLIL draws heavily on content teachers who play a key role in CLIL programmes, for they need to manipulate content from their own subject in addition to the language (Mehisto, Marsh and Jesús Frigols, 2008, p. 11). Yet the main burden lies on language teachers. According to Eurydice, there are three main categories of foreign language teachers (2008, p. 7778). Table 1 bellow shows the categorisation of the qualifications of suitable teachers.

Table 1. European categories of qualifications for foreign language teachers (Eurydice, 2008, p 7786).

\begin{tabular}{|c|c|}
\hline Title & Description of qualification \\
\hline General teacher & $\begin{array}{c}\text { Qualified for teaching of (almost) all subjects in a curriculum, in- } \\
\text { cluding a foreign language, regardless of the specific training. }\end{array}$ \\
\hline Teacher specialist & $\begin{array}{c}\text { Qualified for teaching of two different subjects, one of which is a } \\
\text { foreign language. }\end{array}$ \\
\hline $\begin{array}{c}\text { Semi specialized } \\
\text { teacher }\end{array}$ & $\begin{array}{c}\text { Qualified for teaching of at least three different subjects, one or } \\
\text { more than one of which being a foreign language. }\end{array}$ \\
\hline Unqualified teacher & $\begin{array}{c}\text { Not specified according to Eurydice. Examples: in Great Britain } \\
\text { this can be a language assistant, frequently a native speaker who is } \\
\text { equipped with a university degree for teaching his/her native lan- } \\
\text { guage. }\end{array}$ \\
\hline
\end{tabular}

Beside the abovementioned issue of recruiting the right person for the job, there is another issue that needs to be dealt with and can be an obstacle both in the learning and teaching processes alike. Parents play a decisive role in the decision making process regarding school life. Hence, the research focused on parents' perceptions and attitudes toward early foreign language learning.

\section{Research Focus}

The research focused on parents as an important stakeholder in the learning process. Parents can contribute a great deal to the general atmosphere of learning by exerting either positive or negative influence over their children. Sometimes parents' expectations are set too high, which can lead to disappointment (Smajla, 2014a). All member states of the EU should strive to reach the " $1+2$ policy" goal set by the European Commission in 1995 (p. 47). Recent research in the field of EFLL (Emery, 2012; Enever, Moon, and Raman, 2009; Enever, 2011; Garton, Copland, and Burns, 2011; Graddol, 2006; Wang, 2002, 2007, 2009, as cited in Brumen and Dagarin Fojkar, 2012, p. 29) showed how the European guidelines regarding EFLL are implemented in the classrooms across Europe. A similar research 
was carried out in Slovenia from 2008 to 2010 (Pižorn and Vogrinc, 2010, p. 90), with an important finding, regarding parents: most of the parents involved in the research believed that introducing the learning of a foreign language in year 1 in the primary school should be compulsory. Similar results arrive from a survey carried out by the European Commission (2001), where $93 \%$ of parents across the EU were in favour of their children learning a foreign language. Similarly, a high percentage of parents in the research conducted by Pižorn and Vogrinc (2010, p. 103) showed that more than $99 \%$ of parents believed that learning of a foreign language (FL) is important, $36,4 \%$ of the parents thought that learning of FL should take place as early as year 1 elementary school. It should also be highlighted, that the mentioned research showed $74,2 \%$ of the parents in question deemed their children ought to learn another FL.

\section{Methodology of Research}

\section{General Background of Research}

A small scale research in the form of a case study was carried out at the Vojke Šmuc elementary school at Izola in May and June 2013. English teachers are obliged to carry out 5 to 7 lessons of English in the year 3 each school year. CLIL was chosen as a suitable approach of a foreign language teaching. Parents of the children of the aforementioned class were administered an anonymous questionnaire to be completed and handed in within a week. No suggestions were made as to how the questions should be answered. No direct contact between the parents and the researcher took place to eliminate any possible bias.

\section{Sample of Research}

Class 3. B at the Vojke Šmuc elementary school consisted of 22 students, hence 22 questionnaires were administered to the students' parents. The return rate was satisfactory, since $20(90,9 \%)$ parents returned the questionnaire completed.

\section{Instrument and Procedures}

The research is based on descriptive non-causal method of pedagogical research. The sample was small $(\mathrm{N}=22)$, hence case study was chosen as a fitting strategy of research. A mixed type of questionnaire was used, consisting of open-end questions (8 questions) and questions using a 5-point Likert-scale (5 questions). The open-end questions required parents to write their opinion on topics of relevance to the research (placement of the English lessons for children in the school timetable, frequency and durations of the English lessons, their expectations regarding the English lessons, their view of English lessons in general, whether they felt able enough to offer support to their children at home, what skills ought their children acquire during the English lesons), whereas the questions using a 5-point Likert scale required parents to circle an item reflecting their attitude regarding issues relevant to the research (a-fully disagree to a- totally agree). The questionnaires were completed in the privacy of the parents' homes; moreover, they were not required to provide delicate personal information. The completed questionnaires were handed to the class teacher. 


\section{Data Analysis}

Data was analysed using Microsoft Excel. The results were visualized and presented by the use of histograms, charts, figures and tables.

\section{Results of Research}

The results of the research are presented in the figures below.

\section{Results of question 4}

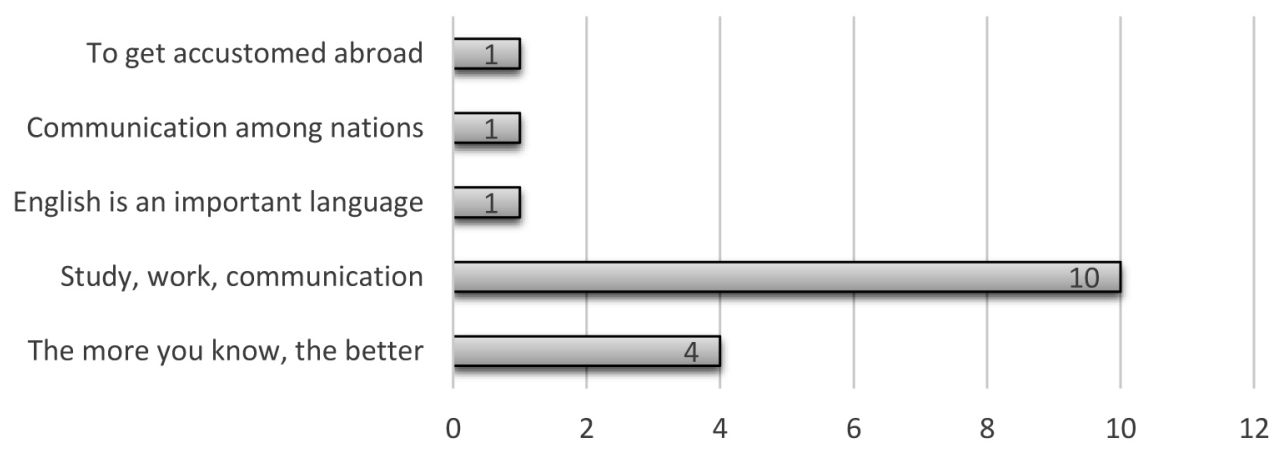

Figure 1: Results of question 4 for parents regarding the importance of speaking a foreign language.

Interestingly, the results of the above mentioned question correlate with those of the children (Smajla, 2014a), for both parents and their children value the possibilities that FL offers in terms of mobility (study, work, and communication).

\section{Results of question 5}

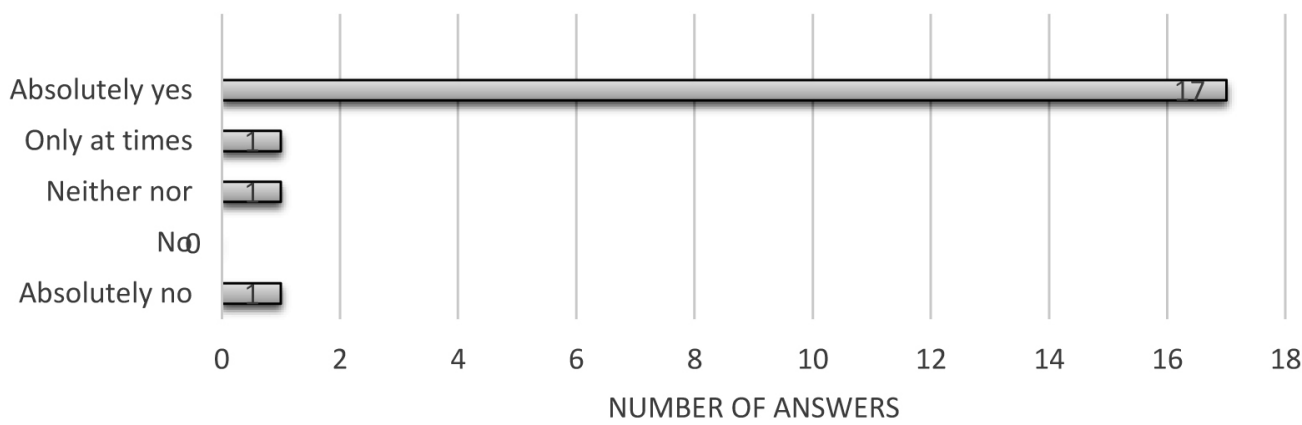

Figure 2: Results of question 5 for parents regarding the importance of integrating content and language learning. 
$77.27 \%$ of parents were in favour of integrating content and language learning in a sensible form, although they weren't specifically explained what the term CLIL meant, but rather deduced the meaning from the description.

\section{Results of question number 13}

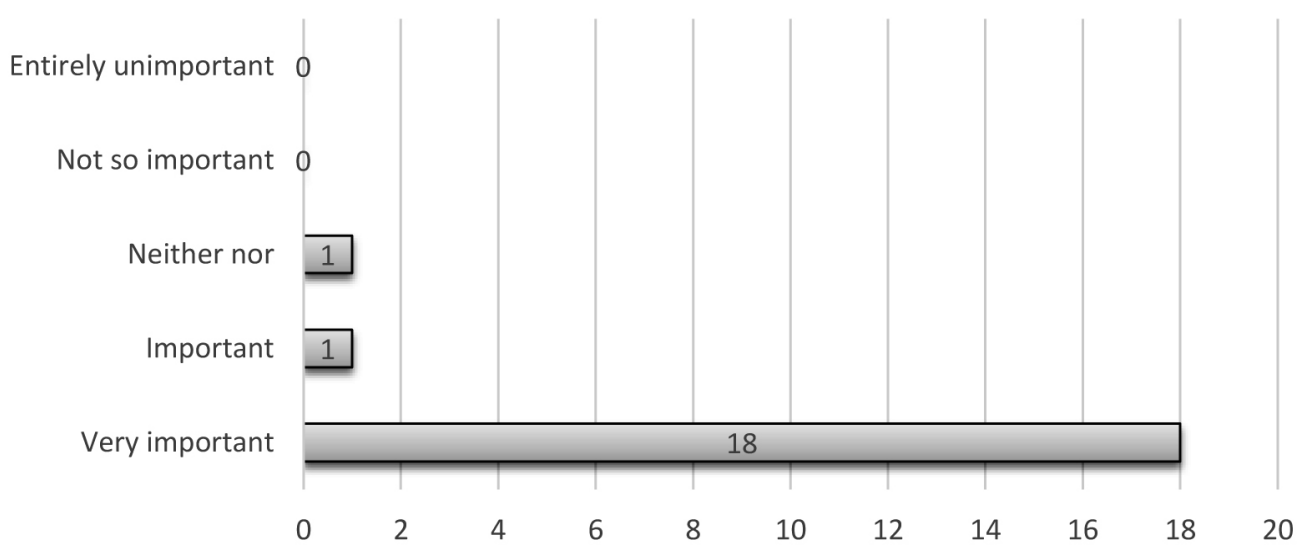

Figure 3: Results of question 13 from the questionnaire for parents regarding wellbeing in EFLL.

18 of 20 parents $(90 \%)$ agreed that wellbeing is an important issue in EFLL. If the Important and Very important items were grouped, we would get an overwhelmingly high percentage $(95 \%)$ of parents attributing a significant value to wellbeing in foreign language class.

\section{Discussion}

The above presented results clearly show the awareness of parents regarding a good command of a foreign language and the importance of nurturing language skills. That has been emphasised in different researches, be it in Slovenia (Pižorn and Vogrinc, 2010; Smajla, 2014a) or abroad (Dobson, Pérez Murillo, and Johnstone, 2010; Snell, Miguel, and East, 2009 as cited in Pižorn and Vogrinc, 2010, p. 95) to name a few.

Perceptions of parents as an important stakeholder have turned out to be very positive in other research studies carried abroad (Dobson et al., 2010, p. 103) and in Slovenia (Smajla, 2014a), where the emphasis is on the parents' role as a partner. Similarly, the results of this research, regarding the parents' perceptions of their child's learning environment, coincide with the one carried out by Dobson et al. (2010, p. 104), for it is the child's personal development and career prospects, communicative skills that are taken into consideration.

As far as wellbeing in early foreign language learning is concerned, the following should be highlighted:

$>$ wellbeing lowers anxiety levels;

$>$ it boosts one's creativity; 
$>$ lessens or even eliminates blockades and stage fright;

$>$ enables students develop their full potential;

$>$ enables students reach a higher level of learning, the so called deep-learning (Smajla, 2014b).

Wellbeing as part of the aforementioned positive psychology offers a great variety of possible strategies, it can be brought about by different approaches in class, yet the most important motivator remains the teacher and his/her values, he/she as a role model. A role model to a growing and developing child is also his/her parent, which brings us back to the title of the paper, to possibilities and limitations. The parent as well as the teacher can and should present a positive role model, be it to a pre-school or elementary school child.

\section{Conclusion}

It should be stated, that children of a certain age are at a certain level of cognitive development, their skills are not fully developed, and therefore parents should bear in mind the delicacy of the developmental stage, not exerting too high a pressure on their children. Bentley (2009) argues, that the role of the parents and their contribution are frequently emphasised by foreign practitioners and researchers. It is parents, who play an important role in the process of introducing changes, since they exert a sometimes decisive influence upon their children by their perceptions and subjective theories (Pižorn and Vogrinc, 2010, p. 91). Wellbeing in early foreign language learning is a branch of research that has been on the rise, since positive psychology has officially set out to conquer schools in the form of different school interventions and projects. Wellbeing, as one of cornerstones of positive psychology, is synergetic with better learning outcomes (Seligman et al., 2009, p. 294) which has been scientifically proven in the PRP programme (Penn Resiliency Program) applied in the Geelong Grammar School in Australia in 2008, to name only one example (Seligman et al., 2009, p. 302).

CLIL promises a great deal, it integrates many teachers in one single person which is also probably the reason why Slovene educational authorities are trying to avoid its introduction into public schools. The officially stated reason is, that it is the Slovenian constitution that does not allow foreign language to be used in the classroom (Uradni list, 1991; člen $11)$.

The current research has made it clear that parents are largely in favour of introducing CLIL approach in a foreign language class. The results cannot be generalized due to a small sample, yet they can spark many a conversation regarding the issue of introducing the CLIL approach into the foreign language class or not. The follow up research should be focused on another relevant stakeholder in the teaching and learning process, the headmasters and their deputies. It happens too often that their opinion prevails over that of the teachers who are directly involved in the teaching and learning process. Their positive or negative attitude toward a foreign language teaching approach can influence greatly that of the parents. Parents' attitudes in turn can influence those of their children and thus, the circle comes full round. In our opinion, the matter needs further scientific treatment and that is, precisely, what language policy makers should do. 


\section{Acknowledgments}

The author acknowledges the support of the Ministry of Education, Science and Sport of Republic of Slovenia and European Social Fund in the frame of the Project: "Innovative pedagogy 1: 1 in the light of competences of the 21st century" on Faculty of Natural Sciences of University of Maribor.
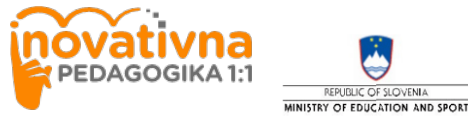

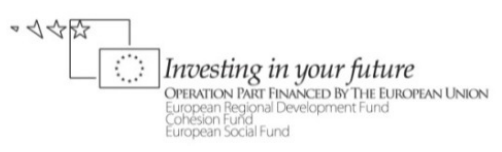

Conesion fund
European Social Fund

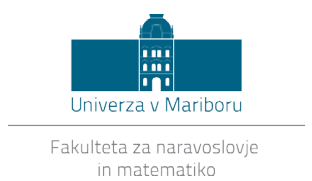

in matematiko

\section{References}

Bentley, K. (2009). CLIL. The issues and challenges. In: Proceedings from The Thrill of CLILa two day meeting for elementary and secondary school English teachers. 6.7. February, 2009, Umag, Croatia. [CD-ROM].

Brumen, M., \& Dagarin Fojkar, M. (2012). Izobraževanje učiteljev za poučevanje tujih jezikov v osnovni šoli v Sloveniji. [Teacher Development in Slovenia for Teaching Foreign Languages at the Primary Level] CEPS Journal, 2 (3), Ljubljana: Pedagoška fakulteta, 29.

Coyle, D., Hood, P., \& Marsh, D. (2010). CLIL: Content and language integrated learning. Cambridge: Cambridge University Press.

Criado, R., \& Sánches, A. (2012). BLOCK 4. The Past meets the present: Language teaching methods in the 20th and 21st century. Universitad de Murcia. Retrieved 27/01/2014, from http://ocw.um.es/humanidades/english-language-teaching-history-approaches-and/classmaterials-1/unit-4.3.5.pdf

Dobson, A., Pérez Murillo, M. D., \& Johnstone, R. (2010). Bilingual education project Spain. Evaluation Report. British Council: Spain.

Emery, H. (2012). A global study of primary English teachers' qualifications, training and career development. ELT Research papers 12-8. Velika Britanija: British Council. Retrieved 13/03/2014, from http://englishagenda.britishcouncil.org/sites/ec/files/B487_ELTRP Emery_ResearchPaper_FINAL_web_V2.pdf

Enever, J., Moon, J., \& Raman, U. (éds.). (2009). Young learner English language policy and implementation: International perspectives. Reading, Velika Britanija: Garnet Education. Retrieved 13/03/2014, from http://www.teachingenglish.org.uk/sites/teacheng/files/ Garnet\%20BC\%20version.pdf

Enever, J. (ed.). (2011). ELLiE: Early language learning in Europe. London, Great Britain: British Council. Retrieved 8/08/2013, from http://www.britishcouncil.org/spain/sites/ default/files/publications/early-language-learning-in-europe-2011.pdf

European Commission. (1995). Teaching and Learning: Toeards the Learning Society. White paper on education and training. COM (95) 590. Brussels.

European Commission (2001). Eurobarometer 55/56. Brussels: European Commission. Retrieved 14/01/2014, from http://ec.europa.eu/public_opinion/archives/eb/eb56/eb56_en.pdf

Eurydice (2008). Key data on Teaching Languages at School in Europe. Brussels: Education, Audiovisual and Cultural Executive Agency. Retrieved March 13, from http://eacea. ec.europa.eu/education/eurydice/documents/key_data_series/095EN.pdf 
Garton, S., Copland, F., \& Burns, A. (2011). Investigating global practices in teaching English to young learners. London, Great Britain: British Council. Retrieved 27/08/2013, from http:/englishagenda.britishcouncil.org/sites/ec/files/B094\%20FINAL\%20Aston\%20 University\%20A4\%20report_2column_V3.pdf

Graddol, D. (2006). English next: Why global English may mean the end of "English as a foreign language". London, Great Britain: British Council. Retrieved 27/08/2013, from http:// www.britishcouncil.org/learning-research-english-next.pdf

Ioannou-Georgiou, S. (2012). Reviewing the puzzle of CLIL. ELT Journal, 66, (4). Special Issue October 2012, 495504.

Llinares, A., Morton, T., \& Whittaker, R. (2012). The roles of language in CLIL. Cambridge: Cambridge University Press.

Marsh, D., Maljers, A., \& Hartiala, A. K. (eds.). (2001). Profiling European CLIL classrooms - languages open doors. Jyväskylä: European Platform for Dutch Education, University of Jyväskylä, 1555. Retrieved 7/03/2014, from http://lakk.bildung.hessen.de/netzwerk/ faecher/bilingual/Magazin/mat_aufsaetze/clilprofiling.pdf

Mehisto, P., Marsh, D., \& Jesús Frigols, M. (2008). Uncovering CLIL: Content and language integrated learning in bilingual and multilingual education. Oxford: Macmillan.

Pižorn, K., Vogrinc, J. (2010). Stališča staršev do uvajanja tujih jezikov v 1.VIO osnovne šole. [Parents' Attitudes to Implementing Foreign Languages in the First Triad of the Primary School in Slovenia]. In Lipavic Oštir, A. and Jazbec, S. (eds). (2010). POT v večjezičnost - zgodnje učenje tujih jezikov v 1. VIO osnovne šole. Ljubljana: Zavod RS za šolstvo. Retrieved 1/03/2013, from http://www.zrss.si/pdf/vecjezicnost.pdf

Seligman, M. E. P., Ernst, R. M., Gillham, J., Reivich, K., \& Linkins, M. (2009). Positive education: Positive psychology and clasroom intervention. Oxford Review of Education, 35, (3), 293-311.

Smajla, T. (2014a). Oduševljenje CLIL-OM. [The Thrill through CLIL]. In: Proceedings from Peti Međunarodni naučno-stručni skup Kulturni identitet u digitalnom dobu. Zenica, 3. i 4. 4. 2014. Univerzitet u Zenici, Filozofski fakultet. Retrieved 30/6/2014, from http:// ff.unze.ba/zbornici-radova

Smajla, T. (2014b). Kaj je koristno vedeti pri zgodnjem učenju tujega jezika. [What Should We Know about Early Learning of Foreign Language]. Vzgoja in izobraževanje, XLV, (1-2), 113122.

Uradni list Republike Slovenije [Official Bulletin of the Republic of Slovenia], št. 33/1991 Retrieved 26/01/2014, from http://www.uradni-list.si/1/content?id=61579

Received 30 June 2014; accepted 20 August 2014

Tilen Smajla

PhD Candidate, Education Sciences, University of Primorska, Faculty of Pedagogy;

English and German Teacher, Elementary School Vojke Šmuc, Prešernova cesta, 4, 6310 Izola,

Slovenia.

E-mail: tilen.smajla@guest.arnes.si 